\title{
The Politics of Riau Malay Identity in the Implementation of Local Democracy
}

\author{
Muhammad Rafi ${ }^{1}$, Titin Purwaningsih ${ }^{2}$, Syed Agung Afandi ${ }^{3}$, Agus Priyanto ${ }^{4}$ \\ 1, 2, 4 Master of Government Affairs and Administration, Universitas Muhammadiyah \\ Yogyakarta, Jl. Brawijaya, Kasihan, Bantul, Yogyakarta, Indonesia 55183 \\ 3 Department of Government Science, Faculty of Social and Political Science, Universitas \\ Abdurrab Pekanbaru, Jl. Riau Ujung No. 73, Pekanbaru, Riau, Indonesia 28291
}

Corresponding author: m.rafi.psc19@mail.umy.ac.id

\section{ABSTRACT}

Article Info :

This article discusses the existence of the use of the Malay identity used by governor candidates in the 2013 Riau Province gubernatorial election. The research method used in this research is the literature study method by analyzing various journals that discuss identity politics and the use of identity in gubernatorial elections. The results showed that in the process, regional representative politics was a strategy that had an essential meaning in the victory of Annas Maamun and Arsyad Juliandi Rachman. However, this strategy also supported by the identity politics of the Riau Coastal and Riau Mainland. Thus, this confirms that the use of the Riau Malay identity in the gubernatorial election is still an additional strategy in the struggle for local democracy and reflects the dark side of democracy in the loss of equality and opportunity for minority groups in Riau Province.

\section{INTRODUCTION}

The issue of identity politics is a problem that is often discussed in Indonesia because many things can be studied and analyzed from various perspectives. In essence, identity politics in Indonesia is more specific to issues of race, culture, politics, and local preferences expressed by elites through the accumulation of their respective interests (Abdullah, 2017). The Regional Division Movement is considered a form of identity politics in the era of decentralization (Albintani, 2018). Also, the politics of local identity becomes thicker because eeach region wants to be led by indigenous of his area (Prayetno, 2016). According to Morowitz (1998), identity politics is a way to provide a clear line in determining who will be included and rejected. Then, according to Heywood (2014), identity politics is a political style that tries to fight against group marginalization by adhering to a positive and assertive sense of shared identity. Furthermore, Identity politics is an ideology that exists in every ethnicity. Its existence is latent and potential and, at any time, can come to the surface as a dominant political force. Today, in a historical period marked by the destructiveness of organizations and 
the delegitimization of institutions, social movements with high impact and transient cultural expression have eliminated. In other words, although not the only one, identity is the primary source of meaning. People are increasingly organizing, structuring the meaning of their lives, not around what they do, but rather, based on what they believe (Hemay \& Munandar, 2016; Salim, 2016).

In the New Order Era, identity politics is something that is prohibited, discussing regional identity is considered as an act against the state (Venus, Syafirah, \& Salam, 2019; Damanik, 2018). The era of decentralization is an indication of the role of the state to advance each region so that in the development process, it can be evenly distributed without discrimination (Pranoto, 2012). Besides, the country has a significant role in optimizing all existing potential (Suaib \& Syifatu, 2016), so that it requires an effective and efficient strategy in achieving it (Kambo, 2015). Decentralization is considered able to optimize the potential that exists in the region to achieve better government management (Jati, 2016). The essential purpose of decentralization as outlined in Law No. 20 of 1999 and Law No. 23 of 2014 concerning the Regional Government is to provide opportunities for development change in each region (Hakim, Hamidi, \& Tampubolon, 2017; Setiawan, Samin, \& Mahadiansar, 2018). It is based on the number of inhabitants, the vastness of the area, and the diversity of ethnicities (Pranoto, 2012).

The reformation period has provided more room for the Indonesian people to gain support for central and national policies. Public participation in determining federal and local policies is a direct democratic political system born out of reform. The direct election political system allows voters to be active in deciding who should be considered representatives of the city. This situation makes regional identities competitive and frequently discussed in the context of local policies. Therefore, the presence of regional autonomy and a direct election political system has helped raise awareness of the importance of identity (Alfarabi, 2019). Furthermore, the transition from the New Order era to the reform era has changed the view of Indonesian society about ethnic identity and decentralization. The emergence of regional identities interprets the revival of identity and devolution in the reform era and new political awareness to restructure local wisdom values based on primordial ethnicity and religion (Alfarabi et al, 2019; Diprose \& Azca, 2020; Kustiawan, 2017). The presence of the era of decentralization and regional autonomy has led to new dynamics for each region (Wahyono \& Meutia, 2018), such as strengthening primordialism in the areas (Damanik, 2018), It has also become an emotional issue by local and national political actors in the power-sharing framework (Haboddin, 2012).

The issue of identity politics will always decorate the journey of democracy in Indonesia. Although momentum of democracy is convincing to enable people to determine the freedom of choice, democracy will continue to face threats due to the existence of identity politics maintained by political elites to achieve specific goals. The resurgence of identity politics in Indonesia after Soeharto caused the journey of democracy in Indonesia for two decades to not progress towards substantial democracy. In the end, Indonesian democracy is still trapped in procedural democracy, only discussing matters of the elite replacement process. Various cases of violence and intolerance and the strengthening of identity sentiment based on ethnicity and religion 
have led to practices of discrimination and exclusion of other different identity groups. This condition is often exploited by political elites who play an essential role in sharpening identity and religious sentiments to gain power and make democracy regress (Mahpudin, 2019).

One of the provinces in the process of presenting its identity is Riau Province, a region considered to have a robust Malay history. The history of Malay in Riau has strong ties with Malay in the Riau Islands, Johor Malay, Malacca Malay, Singaporean Malay, and Minangkabau Malay (Alfarabi et al, 2019a) . Historically, the strengthening of identity politics in Riau Province originated from the lack of strategic positions occupied by Malays, the development of Javanese culture in Malay land, and control of Riau Province's natural resources by large companies that did not provide welfare to the Malay community which frequently interpreted as the absence of the position of the Malay community in their land. Then, when the space for ethnic Malays became open with the presence of regional autonomy policies and the direct election political system, it was finally used by the local Malay elite to change the social position of the Malays in Riau Province. In the socio-cultural field, actions taken by local elites are to strengthen Malay identity through identity symbols such as Selembayung in government buildings and the use of Muslim clothing to show the existence of Malay society. Meanwhile, in the political-economy sector, the actions taken are demanding the role of the Malays to occupy strategic positions in their regions (Alfarabi, 2019).

Furthermore, the Riau Provincial Government and the Riau Malay Customary Institution (LAMR) have collaborated to strengthen the Malay identity through the Riau 2020 Vision Mission which wants to make Riau the centre of Malay culture, not only in Indonesia but also in Southeast Asia (Rafi, Purnomo, \& Wicaksono, 2020). However, although the political elites in Riau Province try to build their Malay identity and make this Malay based on culture, language, and religion as a differentiator from the immigrant community groups, this identity is also subject to debate. For example, for people on the east coast of Sumatra Island, coastal Malay, which includes Dumai, Rokan Hilir, Bengkalis, Meranti Islands, part Indragiri Hilir, part Siak Sri Indrapura, and part Pelalawan. Meanwhile, mainland Malays are known to those from the areas of Pekanbaru, Kampar, Rokan Hulu, and Kuantan Singingi, and parts of Indragiri Hulu are considered different from coastal Malay. The tendency of this dichotomous viewpoint causes the identity politics of the Riau Malay ethnicity to become weak. This dichotomy phenomenon in the way of seeing Malay has also led to the emergence of the desire of most of the elites in the coastal areas of Riau to re-divide Riau Province into Coastal Riau Province (Asrinaldi \& Azwar, 2018).

Then, the presence of the 2020 Riau vision and mission established by the Provincial Government and the Riau Malay Customary Institution as a 'Malay' empowerment forum has the potential for ethnic and ideological conflicts and has the consequence of minority hegemony. It is because the word 'Malay' structurally-legally shows that local ethnicities in the region must dominate regional power. However, the fact indicates that the number of Malay ethnicities in Riau Province does not govern other ethnic groups (Albintani \& Marta, 2020). 
Table 1. Ethnicity in Riau Province

\begin{tabular}{clc}
\hline Etnic & Amount & Percentage \\
& & (\%) \\
\hline Malay & 2.103 .659 & $37,74 \%$ \\
Javanese & 1.431 .598 & $25,05 \%$ \\
Minangkabau & 672.621 & $11,26 \%$ \\
Batak & 400.837 & $7,31 \%$ \\
Banjar & 191.787 & $3,78 \%$ \\
Chinese & 188.897 & $3.72 \%$ \\
Bugis & 139.26 & $2,27 \%$ \\
Sundanese & 103.012 & $1,6 \%$ \\
\hline Amount & 5.726 .241 & $100 \%$ \\
\hline
\end{tabular}

Source: Documentation of Riau Malay Customary Institution, 2019.

Based on the table above (Table 1), it shows that the percentage of Malay tribes is (37.74\%), followed by Javanese (25.05\%), Minangkabau (11.26\%), Batak (7.31\%), Banjar (3.78\%), Chinese (3.72\%), Bugis (2.27\%), and Sundanese (1.6\%). When viewed from the highest number of ethnic groups, the Malays have the highest percentage. Still, if compared with the rate of other ethnic groups, it can be said that the ethnicity of Malays in Riau Province does not dominate and is less in number when compared to different ethnicities. Thus, Indonesia has a variety of identities that are advantageous as a means of political legitimacy in regional elections. An essential aspect of the study of identity politics in Riau Province is to describe the existence of Malay identity in local politics and to find out the extent to which Malay identity can influence the process and results of the direct election political system.

Identity politics in the local realm in Riau Province has frequently discussed in several previous kinds of literature. Haboddin (2012) explains that the problem of youth-indigenous generation accompanies identity politics that occurs in the process of political decentralization, and this is a concern because it will make someone's spirit of nationalism disappear. Furthermore, Asrinaldi \& Azwar, 2018) explains that the involvement of the Riau Malay community in the regional elections is adjusting on how the Malay culture can be maintained and used by governor in running the government. Then, other research explains that in the context of identity politics, the 2020 vision and mission of Riau has the potential to cause ethnic-ideological clashes and social identity issues that do not run linearly because of political interests based on cultural institutions (Albintani \& Marta, 2020; Albintani, 2018). From some of the studies above, it has identified that the previous studies had concentrated more on issues of indigenous and cultural-based political interests. However, what is missing from previous studies is how the existence of ethnic and cultural-based political identities in the process of implementing local democracy. Thus, this study allows for apparent differences in addressing the existence of identity politics in the local realm today.

Another unique thing that became the basis for researchers to choose Riau as the object of research was the problem of indigenous not only at the elite political level but 
also at the grassroots level. If the indigenous have controlled the position of governor, it raises a desire for another position of regents, heads of sub-districts, and also heads of villages. After the indigenous control the vertical strategic positions, it continues to be expanded, with the next target positioning in offices and private companies. The movement of the indigenous of Riau then reflects the high politicization of the 'youthindigenous generation' to control all lines of strategic positions both at the government level and in the implementation of local democracy (Haboddin, 2012). Besides, there is a motive for the formation of a new Malay identity constructed by local elites to provide a more strategic image and social position to the people of Riau. Two new forms of postreformation Malay identification are Muslim Malay and state child Malay. This meaning aims to reposition the position of the Malay community in the socio-political system in Riau (Alfarabi et al., 2019b). In essence, the portrait of the use of a post-reform Malay identity in the gubernatorial elections in Riau Province shows that the existence of the Malay elite is strategic in gaining political support (Asrinaldi \& Azwar, 2018). However, the problem is, will the candidate for a governor who carries the Riau Malay identity be able to win the 2013 gubernatorial election competition in Riau Province? This question is closely related to the phenomenon of strengthening identity politics, which is a paradox in the practice of local democracy. Therefore, this study aims to examine how the politics of Riau Malay identity in the process and implementation of the 2013 gubernatorial election.

\section{METHOD}

In this research, the research method is a literature study from national and international journals that discuss identity politics in Indonesia in general and specifically about identity politics in Riau Province. Then the data in this study were collected through documentation techniques in books, online media, journals, and national and international proceedings (Rahman, 2017). To analyze the obtained data, the author uses content analysis to discuss the contents of the document systematically (Creswell \& Poth, 2016).

In detail, the activity begins with data classification, which includes the stages of grouping data and recording data through an iterative reading process. Then proceed with interpreting detailed data according to the context to understand the meaning of the context in the research substance. As the final stage, the researcher analyzes the interpretation of the data in a descriptive narrative to draw conclusions and answer the research questions posed.

\section{RESULTS AND DISCUSSION \\ History of Malay Culture and Identity Politics in Riau Province}

The area of Riau Province is one of the regions where the Malay culture grows and develops. The term Malay has well-known since $644 \mathrm{AD}$ through Chinese writing, which mentions the word Mo-lo-yeu who sent a messenger to China to bring agricultural products to be presented to the Chinese emperor who showed that the word Malay became a royal name at that time (Efendi, 2014). Referring to the history of Riau, this area was originally an area of the Malay kingdom that was scattered, including the Indragiri Kingdom (1658-1838), the Siak Sri Indrapura Kingdom (1723-1858), the 
Pelalawan Kingdom (1530-1879), the Riau-Lingga Kingdom (1824-1913), Tambusai Kingdom, Rantau Binuang Sakti Kingdom, Rambah Kingdom, Kampar Kingdom, and the Kandis Kingdom. This combination of several royal regions is currently known as the Riau Region Region (Asrinaldi \& Azwar, 2018). The following is an image of the Riau Province map shown:

Figure 1. Map of Riau Province

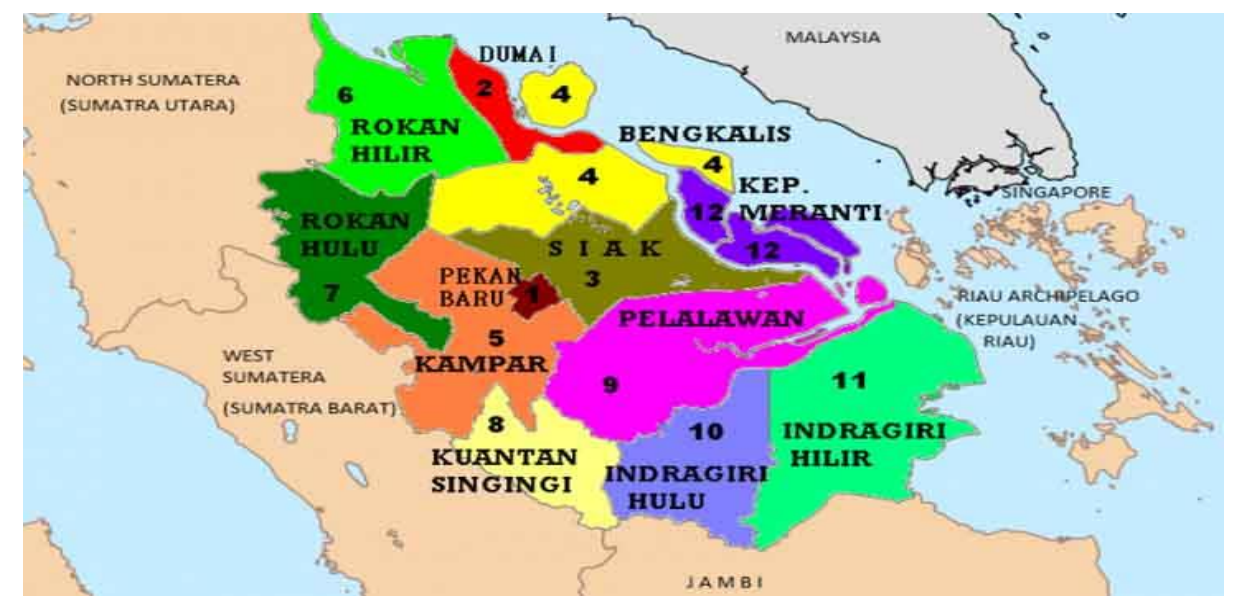

Source: riauonline.com, 2019.

Based on the picture above (Figure 1), it shows that Riau Province has eleven districts and one city. The Malay people continue to build their Malay identity through culture, language, and religion as a classification with immigrant groups. Although currently the Riau-Malay kingdom no longer exists because it has joined the Republic of Indonesia, we can still easily find Riau Malay culture. The Riau-Malay Customary Institution (LAMR) was formed on June 6, 1970, to preserve Malay culture and customs. Local government circles, cultural observers, artists, and universities have initiated the formation of LAMR. So, in a real sense, the Riau Malay Customary Institution (LAMR) aims to preserve the Malay custom, which has increasingly threatened due to the opening of civilization in the Malay world. Furthermore, ethnic Malays as a community have the right to be involved in determining the Malay political format, and ethnic Malays are not a community that is part of a royal ideology-based political system that tends to be authoritarian (Jaya, 2018). The victory of indigenous generation in the 1985 Riau gubernatorial election which was rejected by President Soeharto has become a corrupt memory because of the authoritarian attitude of the New Order which denied the will of the majority of Riau people (Rozi, 2016). The explosion of social movements in Riau Province in 1998-2001 is believed to be as a movement that wants decentralization and is a dynamic of ethnicity in local politics (Hasanudin, 2016). In essence, Malays want their heritage to be protected by local government policies and not used for practical political activities (Asrinaldi \& Azwar, 2018).

\section{The Politics of Riau Malay Identity in the Implementation of Local Democracy}

Currently, identity politics has widely used by local political actors for their political interests. Of the many regions in Indonesia that deal with the issue of indigenous, Riau Province has also made this problem a strategy in implementing local democracy. Also, Riau Province has the uniqueness and strength of a strong resistance 
movement against the central government, even though it ended in defeat. Historically, Riau's loss against the Central Government stems from the desire of most Riau politicians and the public to make their indigenous governors. This desire had long been echoed by regional politicians and found momentum in September 1985. The indigenous candidates for gubernatorial election at that time was Ismail Suko. He served as Secretary of the Regional People's Representative Council. Although his position was not strategic at that time, Ismail Suko had strong influence and support both within the DPRD and the Riau community in general.

These two entities have crucial implications in pressing the central government to support Ismail Suko as governor in the native region of Riau. In his political journey, Ismail Suko made a remarkable history and shocked the political world in Riau. Ismail Suko was considered brave against the New Order government and participated in the Riau gubernatorial election in 1985 with his political rival Imam Munandar from the Golkar Party. From the vote acquisition, Ismail Suko far outperformed and was finally elected gubernatorial of Riau. However, at that time, the power of the New Order regime under President Soeharto did not recognize Ismail Suko as the elected gubernatorial. Nevertheless, politically, Ismail Suko was superior to Imam Munandar's vote. Because urged and forced to continue to retreat by the central government, finally, Ismail Suko was forced to leave, and Imam Munandar was appointed as Governor of Riau for the second time at that time. In the end, this incident gave rise to the political revenge of the Riau Malays against the central government (Haboddin, 2012).

Besides, regional expansion in Riau, especially in the early days of the fall of the New Order regime, had implications for the emergence of local enthusiasm in each region. The expansion of this region has the intention to improve services to the community and equitable development. On the other hand, regional autonomy also creates excessive local enthusiasm. Many areas in Riau Province experienced a division, such as Siak Regency, Rokan Hilir Regency, and Kepulauan Meranti District, which split from Bengkalis Regency, Pelalawan Regency and Rokan Hulu Regency which divided from Kampar Regency and Kuantan Singing Regency which separated from Indragiri Hulu Regency. This spirit of expansion has also given birth to new local elites who occupy strategic positions in government institutions, political parties, and social organizations. Even the emergence of discourse about the formation of the Riau Coastal Province is the impact of the excessive regional zeal of some ethnic Malays (Asrinaldi \& Azwar, 2018). According to Rafi et al., (2020), post-reform Riau Malay identity politics is visible from the three phases of identity formation, namely legitimate identity through the collaboration of the political elite and the Riau Provincial government. Then, through the identity of resistance, the Malay community tried to change the negative view of the ethnic Malays, by providing Islamic values for the entire life of the Malay community. The identity project by the local government and the Riau Malay traditional institution aimed in socializing the importance of Malay culture as the indigenous culture of the Indonesian people.

In the context of implementing local democracy in the 2013 Riau gubernatorial election, many candidates emerged and generally came from former regents and deputy regents of each region. Then, dominantly they compete by carrying out various kinds of branding and political electability as figures of the Malay community in Riau Province.

188 | Journal of Local Government Issues (Logos), 3 (2), September 2020, pp. 182-195 ISSN : $2620-8091$ print | 2620-3812 online 
Table 2. Candidates for Governor and Deputy Governor of Riau Province in 2013

No Name of Candidate for Governor \& Previous Position
Candidate for Deputy Governor

1 Herman Abdullah \& Agus Widayat Mayor of Pekanbaru \& Mainland Malay

Deputy Mayor of \& Coastal Malay

Dumai

2 Annas Maamun \& Arsyad Juliandi The Regent of Rokan Coastal Malay \& Rachman Hilir \& Members of Mainland Malay the DPR-RI

3 Lukman Edy \& Suryadi Khusaini

Minister of PDT \& Mainland Malay
Chairman of DPD
PDIP Riau

4 Achmad \& Masrul Kasmy

5 Jon Erizal \& Mambang Mit
Regent of Rokan Hulu Mainland Malay \& Deputy Regent of \& Coastal Malay Meranti Islands

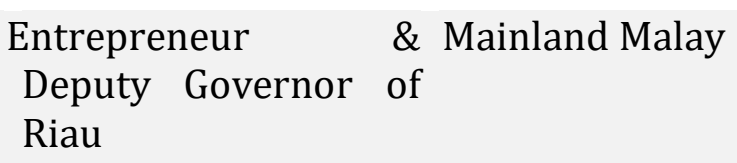

Source: Processed by Researchers from Various Media, 2020.

From the table above (Tabel 2), the pair of candidates is dominated by Malay ethnicity as the majority in Riau. The strength of the Malay identity results in the absence of non-Malay candidates. The Malay identity network steadily built through the figures of traditional leaders and ethnic communities institutionalized in The RiauMalay Customary Institution (LAMR). It has further strengthened identity politics in the governor's contestation's candidacy in Riau. The ethnic groups of immigrants, such as Javanese, Minangkabau, Banjar, Batak, Sundanese, Chinese, and Bugis as ethnic minorities, cannot nominate as the governor and deputy candidates.

This study finds that building a Malay soul in political discourse in Riau is part of an elite effort to place ethnic Malays at the time of the flood of migrants to this area. With the arrival of gubernatorial elections, one of the visible strategies of local elites is to seek maximum support from the Malay community in mainland Riau and coastal Riau to support the candidates for the governor they socialize. In 2013, Candidates for Governor of Riau mostly came from various ethnic Malay mainland and coastal Malay. One interesting thing we found was that the candidates for governor who were nominated from various political parties always took advantage of their regional issues to get votes based on local ties. At the same time, the issue of ethnic Malay was not too dominant and only used it for support from the Malay community. The reason is, ethnicity in Riau Province is not too dominant. Competing governor candidates choose to play the issue of electability and branding politics and raise local issues.

In the 2013 election for the Governor of Riau Province, identity politics applied to legitimize political support. This candidate raises local issues such as local ethnicity being marginalized and losing the local aristocracy due to the centralization of 
government power. The choice of local problems still attracts the public's interest to reexplore political identity during increasingly open local democratic practices. It indicates that the democratic transition is only able to move in the procedural-electoral dimension and has not touched a substantial aspect. The results of the first round of 2013 Riau gubernatorial election, none of the candidate pairs reached $30 \%$ of the vote, and then a second round was held on November 27, 2013. The second round of votes received by the Riau Provincial Election Commission showed that the ballot papers Annas Maamun-Arsyad Juliandi Rachman totalled 1,322,237 or 467,997 votes ahead of his most formidable opponent, namely Herman Abdullah-Agus Widayat who received 854,240 votes. The winning strategy adopted by local political elites in winning elected candidates is to combine the Malay community's support in mainland Riau and coastal Riau, which then involve figures from the two regions to be paired as candidates for governor and deputy. More details available in the following Table 3:

Table 3. Results of the Election of the Gubernatorial of Riau Province in 2013

\begin{tabular}{|c|c|c|c|c|c|}
\hline \multicolumn{3}{|c|}{ First Round Results } & \multicolumn{3}{|c|}{ Second Round Results } \\
\hline $\begin{array}{l}\text { Candidate } \\
\text { Name }\end{array}$ & $\begin{array}{l}\text { Number of } \\
\text { Votes }\end{array}$ & Percentage & $\begin{array}{l}\text { Candidate } \\
\text { Name }\end{array}$ & $\begin{array}{l}\text { Number } \\
\text { of Votes }\end{array}$ & Percentage \\
\hline $\begin{array}{l}\text { Herman } \\
\text { Abdullah-Agus } \\
\text { Widayat }\end{array}$ & 546.714 & $23,00 \%$ & $\begin{array}{l}\text { Herman } \\
\text { Abdullah- } \\
\text { Agus } \\
\text { Widayat }\end{array}$ & 854.240 & $39,25 \%$ \\
\hline $\begin{array}{l}\text { Annas } \\
\text { Maamun- } \\
\text { Arsyad Juliandi } \\
\text { Rachman }\end{array}$ & 685.291 & $28,83 \%$ & $\begin{array}{l}\text { Annas } \\
\text { Maamun- } \\
\text { Arsyad } \\
\text { Juliandi } \\
\text { Rachman }\end{array}$ & 1.322 .327 & $60,75 \%$ \\
\hline $\begin{array}{ll}\text { Lukman } & \text { Edy- } \\
\text { Suryadi } & \\
\text { Khusaini } & \end{array}$ & 333.621 & $14,04 \%$ & & & \\
\hline $\begin{array}{l}\text { Achmad- } \\
\text { Masrul Kasmy }\end{array}$ & 492.665 & $20,73 \%$ & & & \\
\hline $\begin{array}{l}\text { Jon Erizal- } \\
\text { Mambang Mit }\end{array}$ & 318.548 & $13,40 \%$ & & & \\
\hline Invalid vote & 75.739 & & & 43.677 & \\
\hline Total & 2.452 .578 & $100 \%$ & & 2.220 .244 & $100 \%$ \\
\hline
\end{tabular}

Source: Data from the General Election Commission of Riau Province, 2013.

Although the ethnic Malay sentiment that emerged in the 2013 Riau gubernatorial election did not influence the candidate pair's victory, however, the political factor of regional representation by linking the support of the Malay community in the Riau mainland and the Riau Coastal region has proven useful as a 
strategy to win the gubernatorial election competition. Candidate for Governor Annas Maamun as regional representative of Rokan Hilir Regency based on coastal Malay ethnicity who later partnered with Arsyad Juliandi Rachman as representative of Pekanbaru City based on mainland Malay ethnicity who managed to win the most votes and was able to win the competition for the election for Governor of Riau Province in 2013. The following table presents several votes obtained by the region and ethnicity:

Table 4. Results of the 2013 Riau Gubernatorial Election Based on Region and Ethnicity in the Second Round

\begin{tabular}{|c|c|c|c|c|c|c|}
\hline \multirow[t]{2}{*}{$\begin{array}{l}\text { Candidate } \\
\text { Name }\end{array}$} & \multirow{2}{*}{$\begin{array}{l}\text { Regional } \\
\text { Represen } \\
\text { tatives }\end{array}$} & \multirow{2}{*}{$\begin{array}{l}\text { Ethnic } \\
\text { Basis of } \\
\text { Candidates }\end{array}$} & \multicolumn{4}{|c|}{$\begin{array}{l}\text { Results Voting } \\
\text { Dominance }\end{array}$} \\
\hline & & & $\begin{array}{l}\text { Regency/ } \\
\text { City }\end{array}$ & $\begin{array}{l}\text { Herman- } \\
\text { Agus }\end{array}$ & $\begin{array}{l}\text { Annas- } \\
\text { Arsyad }\end{array}$ & $\begin{array}{l}\text { Ethnic } \\
\text { Domina } \\
\text { nce }\end{array}$ \\
\hline $\begin{array}{l}\text { Herman } \\
\text { Abdullah- } \\
\text { Agus } \\
\text { Widayat }\end{array}$ & $\begin{array}{l}\text { Pekanbaru } \\
\text {-Dumai }\end{array}$ & $\begin{array}{l}\text { Mainland } \\
\text { Malay \& } \\
\text { Coastal } \\
\text { Malay }\end{array}$ & Pekanbaru & $\begin{array}{l}163.669 \\
(60,16 \%)\end{array}$ & $\begin{array}{l}108.240 \\
(39,81 \%)\end{array}$ & $\begin{array}{l}\text { Minangka } \\
\text { bau \& } \\
\text { Mainland } \\
\text { Malay }\end{array}$ \\
\hline \multirow{8}{*}{$\begin{array}{l}\text { Annas } \\
\text { Maamun- } \\
\text { Arsyad } \\
\text { Juliandi } \\
\text { Rachman }\end{array}$} & $\begin{array}{l}\text { Rokan } \\
\text { Hilir- } \\
\text { Pekanbaru }\end{array}$ & $\begin{array}{l}\text { Coastal } \\
\text { Malay \& } \\
\text { Mainland } \\
\text { Malay }\end{array}$ & Kampar & $\begin{array}{l}235.344 \\
(75,16 \%)\end{array}$ & $\begin{array}{l}77.750 \\
(24,84 \%)\end{array}$ & $\begin{array}{l}\text { Minangka } \\
\text { bau \& } \\
\text { Mainland } \\
\text { Malay }\end{array}$ \\
\hline & & & $\begin{array}{l}\text { Siak Sri } \\
\text { Indrapura }\end{array}$ & $\begin{array}{l}43.273 \\
(35,84 \%)\end{array}$ & $\begin{array}{l}77.480 \\
(64,16 \%)\end{array}$ & $\begin{array}{l}\text { Mainland } \\
\text { Malay \& } \\
\text { Coastal } \\
\text { Malay }\end{array}$ \\
\hline & & & Rokan Hilir & $\begin{array}{l}24.745 \\
(7,39 \%)\end{array}$ & $\begin{array}{l}310.507 \\
(92,61 \%)\end{array}$ & $\begin{array}{l}\text { Coastal } \\
\text { Malay }\end{array}$ \\
\hline & & & $\begin{array}{l}\text { Rokan } \\
\text { Hulu }\end{array}$ & $\begin{array}{l}50.065 \\
(22,38 \%)\end{array}$ & $\begin{array}{l}173.360 \\
(77,62 \%)\end{array}$ & $\begin{array}{l}\text { Mainland } \\
\text { Malay }\end{array}$ \\
\hline & & & $\begin{array}{l}\text { Indragiri } \\
\text { Hulu }\end{array}$ & $\begin{array}{l}37.012 \\
(33,9 \%)\end{array}$ & $\begin{array}{l}72.048 \\
(66,1 \%)\end{array}$ & $\begin{array}{l}\text { Mainland } \\
\text { Malay \& } \\
\text { Coastal } \\
\text { Malay }\end{array}$ \\
\hline & & & $\begin{array}{l}\text { Indragiri } \\
\text { Hilir }\end{array}$ & $\begin{array}{l}75.973 \\
(33,56 \%)\end{array}$ & $\begin{array}{l}153.271 \\
(66,44 \%)\end{array}$ & $\begin{array}{l}\text { Coastal } \\
\text { Malay }\end{array}$ \\
\hline & & & Pelalawan & $\begin{array}{l}39.297 \\
(35,78 \%)\end{array}$ & $\begin{array}{l}70.525 \\
(64,22 \%)\end{array}$ & $\begin{array}{l}\text { Coastal } \\
\text { Malay }\end{array}$ \\
\hline & & & $\begin{array}{l}\text { Kuantan } \\
\text { Singingi }\end{array}$ & $\begin{array}{l}59.487 \\
(49,4 \%)\end{array}$ & $\begin{array}{l}61.899 \\
(50,6 \%)\end{array}$ & $\begin{array}{l}\text { Mainland } \\
\text { Malay }\end{array}$ \\
\hline
\end{tabular}




\begin{tabular}{lllll} 
& Kepulauan & 21.313 & 48.840 & Coastal \\
Meranti & $(30,38 \%)$ & $(69,62 \%)$ & Malay \\
& Bengkalis & 61.305 & 186.107 & Coastal \\
& & $(32,95 \%$ & $(67,95 \%)$ & Malay \\
& Dumai & 407.441 & 410.109 & Coastal \\
Total Votes & & $(49,19 \%)$ & $(50,22 \%)$ & Malay \\
& & 854.240 & 1.322 .32 & \\
& & $(39,25 \%)$ & 7 & \\
\hline
\end{tabular}

Source: Researcher Processed Data from Various Media, 2020.

The table above (Tabel 4) shows that regional representative politics is a strategy that has essential meaning for the victory of Annas Maamun and Arsyad Juliandi Rachman. However, this strategy is also supported by the identity politics of ethnic Malays in Pesisir Riau and ethnic Malays in mainland Riau who almost dominate the ethnicities in every region. The personal branding of the pair Annas Maamun and Arsyad Juliandi Rachman was also able to attract the public to elect him to be the Governor in Riau Province. It confirms that although the issue of Malay ethnicity is not a dominant factor in winning gubernatorial elections, the use of Malay identity in the implementation of local democracy in Riau Province still functions to get additional support from the Riau Malay community. Furthermore, the existence of the Riau Malay Customary Institution was inseparable from the local political events that took place in Riau Province. In the Riau Malay Customary Institution itself, many legendary figures are also influential community leaders and become role models in the community. That is why many candidates seek public sympathy through support or at least closeness to the Riau Malay Customary Institution.

Then, the description of how the defeat can happen to other candidates with the same ethnicity as the selected candidate is related to the high and even electability in each region of the winning pairs. Dominantly, each candidate has high electability in their respective regions, and it has recorded in the first round, only Jon Erizal was unable to produce the highest votes in his area, namely Bengkalis Regency. However, the superiority of the pair Annas Maamun and Arsyad Juliandi Rachman is about their ability with the winning team to build closeness with people in other areas to elect them as governors based on ethnic Malay and indigenous in Riau. It is visible in the second round, where this pair won the most votes in nine regencies and one city in Riau Province. Besides, a reliable and tested winning team structure from village to district is another factor that determines its victory. Thus, the Riau Malay identity politics in the 2013 Riau gubernatorial election reflects how the dark side of local democracy can eliminate the equality and opportunities of minority groups in the contest for the Gubernatorial elections.

\section{CONCLUSION}

The expression of identity politics prevalent in local-electoral politics has recently become a lousy face of democracy. Regional election should be a venue for 
competing for public problem-solving programs based on equality and inclusiveness, unfortunately has been covered by the mobility of interest sentiments based on pragmatic calculations. The weakness of Party-ID due to the failure of political parties' representation function (Sihidi, Khanifah, \& Romadhan, 2019) makes the ties between both parties candidates and voters neglect the ideological aspects. As a result, the space to exploit identity sentiments has become more exposed.

The identity politics of Riau Malay identity in the implementation of local democracy was obvious in the election of the Governor of Riau in 2013. Prospective governors who were dominantly competing brought various branding as Malay community leaders in Riau Province. Also, regional representative politics that link the existence of Coastal Malay and Mainland Malay identities is one of the strategies of the pair Annas Maamun and Arsyad Juliandi Rachman in winning the election for Governor of Riau Province in 2013. This research has limitations to analyze the existence of Malay identities in the gubernatorial elections of Riau Province in 2013. For this reason, we recommend that a similar follow-up study in the future, focusing on the phenomenon of how the existence of the use of Riau Malay identity in the current gubernatorial elections.

\section{REFERENCES}

Abdullah, A. (2017). Membaca Komunikasi Politik Gerakan Aksi Bela Islam 212: Antara Politik Identitas dan Ijtihad Politik Alternatif. An-Nida', 41(2), 202-212.

Albintani, M. (2018). Politik Identitas dan Negara Bangsa di Riau. Nakhoda: Jurnal Ilmu Pemerintahan, 17(1), 1-13. http://dx.doi.org/10.35967/jipn.v17i1.7054

Albintani, M., \& Marta, A. (2020). Provinsi" Istimewa Melayu Riau Kepulauan"(Gagasan Permulaan). Nakhoda: Jurnal Ilmu Pemerintahan, 19(1), 56-74.

Alfarabi, A. (2019). Simbol Eksistensi Identitas Etnik Melayu Riau di Pekanbaru. Jurnal Kaganga, 3(1), 67-77. http://dx.doi.org/10.35967/jipn.v19i1.7833

Alfarabi, A., Venus, A., Syafirah, N. A., \& Salam, N. E. (2019a). Media Identitas Melayu Pascareformasi Di Indonesia. International Journal of Multicultural and Multireligious Understanding, 6(7), 21-31.

Alfarabi, A., Venus, A., Syafirah, N. A., \& Salam, N. E. (2019b). Rekonstruksi Stereotip Negatif Etnik Melayu. Jurnal Manajemen Komunikasi, 3(2), 131-141. https://doi.org/10.24198/jmk.v3i2.20505

Asrinaldi, A., \& Azwar, A. (2018). Dimensi Kekuasaan Penghulu Adat Melayu Riau dalam Pelaksanaan Demokrasi Lokal. Jurnal Antropologi: Isu-Isu Sosial Budaya, 20(1), 57-69.

Creswell, J. W., \& Poth, C. N. (2016). Qualitative Inquiry and Research Design: Choosing Among Five Approaches. London: Sage publications.

Damanik, E. L. (2018). Politik Lokal: Dinamika Etnisitas pada era Desentralisasi di Sumatera Utara. Medan: Simetri Institute.

Diprose, R., \& Azca, M. N. (2020). Conflict Management in Indonesia's Post-Authoritarian Democracy: Resource Contestation, Power Dynamics and Brokerage. Conflict, 


$\begin{array}{lcccc}\text { Security } & \& & \text { Development, } & 20(1), & \text { 191-221. } \\ \text { https://doi.org/10.1080/14678802.2019.1705074 } & & \end{array}$

Efendi, R. (2014). Riau Al-Munawwarah (Menuju Masyarakat Madani Untuk Mewujudkan Visi Riau 2020). Yogyakarta: Pustaka Pelajar.

Haboddin, M. (2012). Menguatnya Politik Identitas di Ranah Lokal. Jurnal Studi Pemerintahan, 3(1).

Hakim, A., Hamidi, W., \& Tampubolon, D. (2017). Analisis Dampak Pemekaran Daerah Ditinjau dari Aspek Percepatan Pertumbuhan Ekonomi dan Peningkatan Kualitas Pelayanan Publik (Studi Pemekaran Kabupaten Kepulauan Meranti dari Kabupaten Bengkalis). Jurnal Online Mahasiswa, 4(1), 843-857.

Hasanudin, H. (2016). Anatomi Gerakan Sosial di Riau: Refleksi Atas Dinamika Perlawanan Masyarakat Riau terhadap Negara 1998-2001. Jurnal Sosiologi Reflektif, 8(2), 161-175.

Hemay, I., \& Munandar, A. (2016). Politik Identitas dan Pencitraan Kandidat Gubernur terhadap Perilaku Pemilih. POLITIK, 12(1), 1737-1747.

Heywood, A. (2014). Politik edisi ke-4. Yogyakarta: Pustaka Pelajar.

Jati, W. R. (2016). Inkonsistensi paradigma otonomi daerah di Indonesia: Dilema sentralisasi atau desentralisasi. Jurnal Konstitusi, 9(4), 743-770. https://doi.org/10.31078/jk\%25x

Jaya, A. C. (2018). Konsep Nation-State dalam Pemikiran Ideologi Politik Melayu Islam pada Abad Ke-19 M (Studi Pemikiran Abdullah Bin Abdul Kadir Munsyi (17871854). Tamaddun: Jurnal Kebudayaan dan Sastra Islam, 18(2), 134-146. https://doi.org/10.24042/tps.v15i1.3684

Kambo, G. A. (2015). Etnisitas dalam Otonomi Daerah. The Politics: Jurnal Magister Ilmu Politik Universitas Hasanuddin, 1(1), 1-8.

Kustiawan. (2017). Kebangkitan Politik Etnis dan Desentralisasi Dalam Bingkai Negara Kesatuan Republik Indonesia. Prosiding Pelaksanaan Pilkada Serentak yang Sehat, Jujur, Adil dan Akuntabel Pertemuan Forum Dekan Ilmu-Ilmu Sosial PTN Seindonesia, 129-153..

Mahpudin, M. (2019). Demokrasi dan Kebangkitan Politik Identitas: Refleksi Perjalanan Demokrasi Indonesia Pasca Orde Baru. International Journal of Demos (IJD), 1(1), 1-18. https://doi.org/10.37950/ijd.v1i1.1

Morowitz, D. L. (1998). Demokrasi Pada Masyarakat Majemuk"'” dalam Larry Diamond dan

Mars FPlattner Nasionalisme, Konflik Etnik dan Demokrasi. Bandung:ITB Press.

Pranoto, S. W. (2012). Anomali Desentralisasi Etnisitas Memancing Disintegrasi? AGASTYA: Jurnal Sejarah dan Pembelajarannya, 2(2), 1-11. http://doi.org/10.25273/ajsp.v2i2.1456

Prayetno, P. (2016). Menguji Hak Politik dalam Kontestasi Politik; Analisis Terhadap Politik Identitas Etnis di Desa Perdamaian, Kecamatan Binjai, Kabupatan Langkat. HUMANITAS: Jurnal Kajian dan Pendidikan HAM, 7(2), 39-54. https://doi.org/10.24114/hpu.v7i2.10890

194 | Journal of Local Government Issues (Logos), 3 (2), September 2020, pp. 182-195 ISSN : $2620-8091$ print | 2620-3812 online 
Rafi, M., Purnomo, E. P., \& Wicaksono, B. (2020). Riau Malay Identity Politics. Jurnal Antropologi: Isu-Isu Sosial Budaya, 22(1), 112-120. https://doi.org/10.25077/jantro.v22.n1.p112-120.2020

Rahman, M. S. (2017). The Advantages and Disadvantages of Using Qualitative and Quantitative Approaches and Methods in Language" Testing and Assessment" Research: A Literature Review. Journal of Education and Learning, 6(1), 102-112.

Rozi, S. (2016). Nasionalisme, Demokratisasi, dan Sentimen Primordialisme di Indonesia: Problematika Identitas Keetnisan versus Keindonesian pada Studi Kasus Aceh, Papua, Bali, dan Riau. Jurnal Penelitian Politik, 6(1), 75-84. https://doi.org/10.14203/jpp.v6i1.529

Salim, K. (2016). Politik Identitas di Maluku Utara. POLITIK, 11(2), 1667-1678.

Setiawan, R., Samin, R., \& Mahadiansar, M. (2018). Dampak Desentralisasi terhadap Kapabilitas Kepala Daerah (Studi Kasus Gubernur Riau Periode Tahun 20082013). Jurnal Ilmu Administrasi Negara (JUAN), 6(2), 15-24.

Sihidi, I. T., Khanifah, L. N., \& Romadhan, A. A. (2019). Relasi Politik Uang Dan Party-Id di Indonesia.

Cosmogov,

$5(2)$,

204-220.

https://doi.org/10.24198/cosmogov.v5i2.23293

Suaib, E., \& Syifatu, W. (2016). Desentralisasi dan Oligarki Predator di Wakatobi: Peran Oligarki dan Elit Penentu dalam Pembangunan Perdesaan. Jurnal Penelitian Politik, 13(2), 167-191. https://doi.org/10.14203/jpp.v13i2.557

Venus, A., Syafirah, N. A., \& Salam, N. E. (2019). Elite Lokal dan Upaya Pembentukan Wajah Baru Identitas Melayu di Indonesia Pascareformasi (Local Elite and New Face Formation Effort for Identity of Malays in Indonesia Post-Reformation). Akademika, 89(3), 143-154.

Wahyono, E., \& Meutia, F. S. (2018). Diskursus Demokrasi Pancasila dalam Lintas Perspektif Etnisitas. Journal of Government and Civil Society, 1(2), 121-133. http://dx.doi.org/10.31000/jgcs.v1i2.441 